\title{
Confronting the Challenges of MALL: Distraction, Cheating, and Teacher Readiness
}

\author{
https://doi.org/10.3991/ijet.v15i02.11325 \\ Rastislav Metruk \\ University of Žilina, Žilina, Slovakia \\ rastislav.metrukefhv.uniza.sk
}

\begin{abstract}
Mobile technologies appear to be gaining in popularity regarding foreign language instruction as they have recently proliferated in academic environments. M-learning opens up new possibilities and opportunities for both teachers and students, and it is inevitable that methodological approaches to pedagogy and ways of teaching foreign languages are accordingly adjusted and reevaluated. Despite numerous significant advantages mobile technologies offer, scholars and educators have to take into consideration some barriers and limitations in this respect, and respond to both existing and future challenges. Moreover, the studies on MALL (mobile-assisted language learning) seem to be predominantly focused on benefits of specific technological advances when the advantages of MALL are discussed. This article attempts to present a critical review of the literature which deals with MALL as further research and exploration in this area is necessary, especially with regard to challenges and barriers language teachers face when m-technologies are employed. Three major drawbacks related to using mobile technologies in teaching are predominantly discussed, namely learner distraction, cheating, and teacher perception and readiness. Moreover, proposing feasible solutions to the challenges and barriers is also discussed in the article.
\end{abstract}

Keywords-Mobile technologies, MALL drawbacks and disadvantages, perception, cheating, readiness, EFL learner

\section{Introduction}

The introduction of digital technologies in the process of teaching and learning is a topic which spans the literature on educational technology since the 1980s [1]. Since then, modern technologies have undergone a rapid development, and the world is currently witnessing a rapid scientific and technological leap [2]. Mobile devices have become an inseparable part of each individual [3], and contemporary global issues require people specializing in various fields to effectively communicate in foreign languages [4], [5]. According to [6], the use of computers, mobile devices and the Internet is expected to continue increasing since technology is more accessible, in particular for people in developing countries. It is also English for specific purposes instruction, which 
is positively influenced by the advantages of modern technologies [7], [8]. It is, therefore, inevitable that educators worldwide tailor their ways of teaching in relation to the integration of technologies into teaching so as to become competent and skilled teachers of foreign languages.

It should be also noted that rather limited research has been performed in relation to the perceptions of language teachers on the implementation of MALL [9]. It appears that mobile learning requires still a long way to go, and the existing barriers are represented by the lack of policy support as well as governmental investment and negative attitudes towards cell phones in the school environment due to cyber-bullying, cheating, etc. [10]. Conducting further research in this area in order to cast more light on this matter is strictly necessary, also due to the fact that MALL will occupy a powerful role in teaching and learning foreign languages in years to come.

In its essence, mobile learning can be regarded as teaching and learning using mobile technologies such as mobile phones, media players, PDAs, smartphones, and tablet computers which are potentially available anywhere and anytime (Duman, Orhon \& Gedik, 2014) [11]. Without a shadow of a doubt, employing MALL (Mobile-assisted language learning) offers numerous considerable advantages. Zaki and Yunus (2015) [12] mention the following features of mobile learning: mobility, ubiquity, wireless networking, interactivity, accessibility, and privacy. According to Pachler, Bachmair and Cook (2010) [13], the following important features (among other things) of mobile devices that make them attractive from educational standpoint can be recognized: increasing portability, functional, multimedia convergence, ubiquity, personal ownership, social interactivity, context sensitivity, location awareness, connectivity, and personalization. Huang, Huang, Huang and Lin (2012) [14] state that mobile technologies have numerous advantages such as flexibility, low cost, small equipment size and userfriendliness.

However, integrating modern technologies into teaching and learning in order to facilitate learning poses challenges for education institutions, and there exist some drawbacks mobile technologies suffer from, which need to be considered. Tafazoli, Parra and Huertas-Abril (2018) [15] maintain that problems with MALL may involve limited audio-visual contact, small screen and keyboard, limited length of messages, data storage, and the like. Apart from discussing physical properties and technical features of mobile devices, the following disadvantages of mobile learning can be identified: the potential for distraction or unethical behavior, physical health concerns, and data privacy issues. Plenty of school leaders regard mobile phones as something that hinders meaningful learning, also because of potential distractions from ringtones, emails, texting, tweeting, and cheating (Trilling \& Fadel, 2009) [16]. O'Bannon and Thomas (2015) [17] and Thomas, O'Bannon and Britt (2014) [18] perceive cheating, disruptions, cyberbullying, and accessing inappropriate content as formidable barriers with regard to using cell phones in the classroom.

Further drawbacks could be identified, and there is every likelihood that with newer technological affordances which will be emerging in large amounts, more disadvantages will be recognized. 


\section{Mobile Technologies and Learner Distraction}

Certain concerns are aroused when it comes to students being distracted by using mobile devices [19], [20], [21], [22], [23], [24]. The learners can spend time texting, surfing the web or chatting online with their peers, which results in not paying attention to the teaching and learning process. In a similar way, [25] explain that the pedagogical limitations involve the lack of students' concentration and work interruption when using mobile devices. [26] also indicate that concerns about distraction, classroom disruption as well as potential cheating may also have an impact on teachers' decision to allow using mobile devices in the classroom.

[27] Maintain that a contradictory tendency is happening in higher education at the moment - despite the fact that cell phones and other mobile devices are completely embedded in the life of students, instructors normally see these devices, cell phones in particular, as something that causes distractions, and is unnecessary for learning purposes. Thus, teachers have to adopt somewhat new approaches and ways of teaching so that using mobile technologies actually facilitates learning.

[28] Regards distractions in the classroom as one of the adverse effects of using mobile phones among Nigerian university students, suggesting that students ought to turn off their cell phones or put them on silent mode when receiving lectures. Moreover, the students should devote their cell phone usage time to research and academic activities, not being engaged in social networking and pinging. [29] also asserts that some language teachers regard mobile devices as distracting tools. He further explains that the popularity of cell phones ought to be exploited so that students' appeal for mobile technology is harnessed into classroom training.

The data analysis of the study conducted by [30] revealed that the Iranian EFL learners use mobile devices primarily for non-academic purposes. Another study carried out by [31] aimed at exploring the impact of using mobile phones during a class lecture on student learning. The results demonstrated that those students who were not using mobile phones during the lecture wrote down $62 \%$ more information in their notes, and their notes were also more detailed. Moreover, the students could recall more detailed information from the lecture, and scored better on a multiple choice test in comparison to the students who were actively using their mobile phones during the lecture. The majority of 296 college students in another study that was performed by [32] believe that instructors are highly unaware of the degree to which students are engaged in cell phone activities such as browsing the Internet, sending pictures, or visiting social networking sites.

It is of paramount importance that further exploration is carried out as far as the distraction within the implementation of mobile technologies into the learning process is concerned. When learners are distracted, modern technologies hinder rather than facilitate the learning process. 


\section{Mobile Technologies and Cheating}

One of the challenges of modern technologies instructors need to rise to is that students may be enabled to cheat by means of mobile technologies [33]. In a similar way, [34] assert that cheating and dishonesty has become an ethical dilemma when it comes to technology enhanced education. [35] Explains that the advent of technology has, apart from potentially supporting qualification, socialization, and subjectification of students, also led to cheating, plagiarizing, and colluding with students to behave unethically. Cheating by means of technology includes (but is not limited to) using cell phones, programmable calculators, pagers, personal digital assistants, computers, the Internet, etc. so as to gain unfair advantage in examinations.

The advanced features of today's cell phones allow students to choose from a number of ways of cheating in examinations. Learners may constantly communicate with individuals outside the classroom via email or short messaging services. Using the cell phone camera, learners can snapshot questions and send them through email or Whats App to outsiders, and in the same manner, they can receive answers. Furthermore, students can post questions online and obtain responses instantaneously. Alternatively, learners may use search engines in order to find answers, or pack their cell phones with lecture notes, ebooks, and other unauthorized materials pertinent to the examination in question. Other applications installed in their cell phones such as dictionaries or scientific calculators can also be used. [36].

[37] Performed a study which reports that the majority of graduating, college bound, high-school seniors either had an experience in cheating or at least they possessed knowledge of cheating by their peers. The study conducted by [38] shows that although both students and teachers at Batna-2 University use mobile devices so as to facilitate and support the learning process, nearly $35 \%$ of the students confess that mobile devices are helpful tools in terms of cheating at examinations. The leading concerns expressed by a study which aimed at examining the perceptions of 92 preservice teachers (enrolled in a Midwestern liberal arts university) involved classroom disruptions and cheating [39]. Bower and Sturman (2015) [40] examined the perceptions of 66 educators from around the world who thought about themselves as having good or very good understanding of wearable technologies. Apart from raising issues about potential distraction, overreliance on wearable technology, etc., it was also cheating that was reported. The study of [41] concentrated on ethical considerations which might come into being when students bring their cell phones in the classroom. More than $50 \%$ of teachers perceived cell phones as a distraction in the classroom, and nearly a half of them expressed their concerns about cheating. [42] conducted a case study which attempted to imprint academics' knowledge, beliefs, and strategies with regard to plagiarism and cheating. The academics involved in the study admit that they are confronted with both plagiarism and cheating in undergraduate and postgraduate level.

A fine example of cheating by means of mobile technologies can be represented by wireless HD (high definition) WiFi live streaming camera glasses and wireless earphones (possibly covered by a candidate's hair). Using these technological advancements, the candidate can, with a little help from an individual outside, easily, inconspicuously, and calmly score $100 \%$ in virtually any written test, having little or no 
knowledge of the subject matter. It should be also noted that there are copious amounts of ways of cheating.

[10] Maintains that exposing learners to risk environments containing inappropriate material or hostile environments such as cyber bullying, sexual offenses or potential cheating during examinations represent some additional roadblocks towards the adoption of mobile learning in the USA. If the instructor adheres only to traditional countermeasures to neutralize cheating, it is extremely likely that unethical academic behavior, arising out of the use of modern technologies, will go unnoticed. Traditional methods used for the detection of cheating may not be entirely successful when it comes to preventing cheating in examinations in this day and age. Therefore, new strategies have to be implemented so as to skillfully manage the use of technological advancements and innovations for illegitimate purposes.

[43] Explain that the following measures can by employed so as to prevent learners from cheating. One is to use jamming devices (jammers), which prevent radio devices from transmitting and receiving signals. It should be also noted that one needs to be careful about the legality of such devices. Another device which can be used is the socalled faraday Cage. Metal would be built into the walls of a room in order to block electromagnetic waves. As a result, mobile phones in examination rooms would have considerably reduced signals (if any). Another option would be the implementation of detection devices, CCTV cameras, or metal detectors.

[44] Explains that one of the approaches to prevent using cell phones from cheating is to perform a manual inspection. This, however, cannot reveal the cell phones all the time, and some students can remain undetected. In connection with this, [44] proposed a prototype of a cell phone sniffer which detects the presence of mobile phones in the examination rooms. They further assert that in order to avoid an unauthorized use of cell phones in the restricted areas, the implementation of cell phone detectors is unavoidable.

\section{Teachers' Perception and Readiness}

Another formidable challenge which needs to be addressed is teachers' attitudes towards MALL, and how they adjust to new ways of teaching. Undoubtedly, further research has to be performed in the field of teachers and their readiness towards the implementation of modern technologies in their classrooms. Research focusing exclusively on teachers' perception and readiness with regard to mobile learning is very limited [45].

[46] Explain that many teachers oppose the change in terms of employing new technologies in the teaching and learning process as they do not consider themselves to be a part of a new learning culture. Furthermore, technology-oriented trainings and resources may not satisfy the needs of individuals in terms of understanding the nature of learning. The survey carried out by [9] reveals that EFL teachers did not possess the required skills to use and develop MALL activities. [47] examined if teachers' acceptance of technology could have an impact on their readiness for pedagogical use of mobile technology. The results indicate that despite positive acceptance of technology, 
the teachers' readiness for the implementation of cell phones in teaching and learning was at a considerably lower level.

Another study, conducted by [48], explored the readiness of teachers regarding the acceptance of technology for pedagogical use of mobile phone technology. The results suggest that in spite of the fact that the teachers were highly motivated regarding the use of mobile technology in the learning process, they still did not seem to be ready for using mobile technologies in their classes due to the lack of competence as well as lack of access to the resources available. The research by [49] demonstrates that the perception of Turkish prospective teachers of mobile learning is, generally, low, and many of the teachers possess no information about mobile learning. Another study by [30] reports that despite the fact the some Iranian EFL teachers favor using mobile devices in the classroom, some of them prevent their learners from using them.

The results of the research which examined perceptions of preservice teachers about using m-phones and laptops as mobile learning tools suggest that there is an urgent need to increase awareness among student teachers in regard to the concept of m-learning [50]. Another study carried out by [51] also concludes that teachers are not prepared for mobile learning. In connection with this, [52] maintain that teachers must have professional development which would encourage enthusiasm, willingness, and skill in techniques in order to successfully integrate mobile devices in the classroom.

Very often, new technologies are simply dumped into the class, providing no guidance to the teachers on how the technology ought to be used and what benefits both the teachers and students may receive. It is generally expected that the teachers will (automatically) learn how to successfully and effectively incorporate mobile technologies into the teaching and learning process. This may result into unsuccessful experiments and frustration with static educational results [53].

It is apparent that educators need to build increased awareness when it comes to pedagogical approaches in terms of the implementation of mobile technology into their classrooms. When the instructors have gained enough knowledge, they will be ready to take their ways and methods of teaching to the next level, and with the help of technology, the teaching and learning process ought to be facilitated.

\section{Conclusion and Recommendations}

Incorporating mobile technologies into the classrooms yields, without a doubt, a number of considerable benefits, and there are numerous studies that support the notion that modern technologies facilitate and enhance learning. However, there also exist several disadvantages both teachers and learners face, and these need to be overcome.

This article predominantly focused on three drawbacks related to using mobile technologies in teaching, namely learner distraction, cheating, and teacher perception as well as their readiness. These three downsides can be regarded as severe restrictions on teaching and learning process, and they need to be addressed. Unfortunately, little research that would concentrate on the three disadvantages has been conducted up to date, and further exploration in this area is absolutely necessary. 
It is of vital importance that mobile technologies do not perform the role of distractors, but rather help and facilitate the learning process. Instructors have to learn how the mobile technologies are used in favor of learning, and they need to make sure that their students do not use modern technologies for chatting with their peers, visiting social-networking websites, or performing other non-academic activities. Rather than that, wearable technologies must lead to the enhanced teaching and learning.

In a similar way, teachers have to prevent their learners from using mobile devices for the purposes of cheating as ICTs offer a vast number of opportunities in terms of cheating at examinations. Various devices have become smaller and smaller in size, and can be connected to other devices in a numerous of ways; this increases the possibility of cheating, and decreases the chance of revealing the presence of cheating. Thus, teachers need to be on the alert before and during testing. Indubitably, this can be regarded as a daunting task because should the instructors only stick to traditional methods used for the purposes of eliminating cheating, unethical behavior aided by modern technologies will probably go unnoticed due to the fact that smartwatches, smart glasses, or other smart devices may look indistinguishable from the ordinary counterparts of theirs. New ways of detecting cheating such as using various types of jammers, detection devices, CCTV cameras, etc. have to be employed, and this is definitely a formidable task. Incorporating such affordances requires effort, time, and investment.

Finally, it is also the teacher perception and, (perhaps) more importantly, their readiness regarding the use of modern technologies in their classes which is of major significance. Although the research suggests that instructors frequently display positive attitudes towards the implementation of mobile technology in their classes, they often do not appear to be ready to use them effectively. The instructors do not seem to possess the necessary skills as they are automatically expected to the new technologies in a way which would facilitate and improve the learning process. Therefore, educators' awareness has to be developed, and they need to undergo training so as to understand and use these technologies effectively and appropriately. Institutions that provide (prospective) teachers with training also play a major role as their instructors need to be reasonably familiar with ICTs. Furthermore, subjects dealing with modern technologies and their use within EFL teaching should become an obligatory part of teacher training courses. It should be also emphasized, that further research is desperately needed in this area.

It is apparent that the flood of modern technologies and various mobile devices, smartphones in particular, will continue to expand in years to come. This will have a considerable impact on both teaching and learning. Although there is every likelihood that the advantages will outweigh the drawbacks, the disadvantages of integrating ICTs into the teaching and learning process must not be underestimated. Therefore, it is also the perception and readiness of both teachers and learners along with how they will tailor their ways of teaching and learning, which is of profound importance.

\section{$6 \quad$ References}

[1] Pedro, L., Barbosa, C., \& Santos, C. (2018). A critical review of mobile learning integration in formal educational contexts. International Journal of Educational Technology in Higher Education, 15(1). https://doi.org/10.1186/s41239-018-0091-4 
[2] Eltahir, M., Al-Qatawneh, S., \& Alsalhi, S. (2019). E-Textbooks and Their Application Levels, from the Perspective of Faculty Members at Ajman University, U.A.E. International Journal of Emerging Technologies in Learning, 14(13), 88-104. https://doi.org/10.3991/ijet.v14i13.9489

[3] Metruk, R. (2019). The Call of the MALL: the Use of Smartphones in Higher Education. A Literature Review. Revista Dilemas Contemporáneos: Educación, Política y Valores, 6(3), 1-22. Retrieved from https://dilemascontemporaneoseducacionpoliticayvalores.com/_ files/200004733-ea787eb6e4/19.05.52\%20El\%20llamado\%20del\%20MALL.\%20El\%20u so\%20de\%20los\%20tel\%C3\%A9fonos\%20inteligentes.....pdf

[4] Nikolajová-Kupferschmidtová, E., Štubňa, P., \& Kučmová-Lenzi, A. (2018). Rebus Linguae. On Selected Aspects of Languages for Special Purposes. Uherské Hradiště: Vědecké nakladatelství Fakulty veřejnoprávních a ekonomických studií.

[5] Štubňa, P. (2019). Simultaneous Interpretation Quality Assessment. Revista Dilemas Contemporáneos: Educación, Política y Valores, 6, 1-15. Retrieved from https://dilemascontemporaneoseducacionpoliticayvalores.com/_files/200005392-4b89f4c8 65/EE\%2019.07.06\%20Evaluaci\%C3\%B3n\%20de\%20la\%20calidad\%20de\%20la\%20inte rpretaci\%C3\%B3n\%20simult\%C3\%A1nea.pdf

[6] Poushter, J. (2016). Smartphone Ownership and Internet Usage Continues to Clim in Emerging Economies. Washington> Pew Research Center. Retrieved from http://www. pewglobal.org/2016/02/22/smartphone-ownership-and-internet-usage-continues-to-climbin-emerging-economies/

[7] Karpenko, Y. (2017). Multimedia Computer Software for the Professional Training of Prospective Specialists in Foreign Languages for Preschool and Primary Education. Information Technologies and Learning Tools, 57(1), 50-55. Retrieved from https://journal.iitta.gov.ua/index.php/itlt/article/view/1513/1130

[8] Zhang Y., \& Zuo, L. (2019). College English Teaching Status and Individualized Teaching Design in the Context of Mobile Learning. International Journal of Emerging Technologies in Learning, 14(12), 85-96. Retrieved from https://doi.org/10.3991/ijet.v14i12.10704

[9] Dashtestani, R. (2013). Implementing Mobile-assisted Language Learning (MALL) in an EFL Context: Iranian EFL Teachers' Perspectives on Challenges and Affordances. The JALT CALL Journal, 9(2), 149-168. Retrieved from https://files.eric.ed.gov/fulltext/EJ11 08023.pdf

[10] Tsinakos, A. (2013). State of Mobile Learning Around the World. In A. Tsinakos and M. Ally (Eds.) Global Mobile Learning Implementations and Trends, p. 4-44.

[11] Duman, G., Orhon, G., \& Gedik, N. (2014). Research Trends in Mobile Assisted Language Learning from 2000 to 2012. ReCALL journal, 27(2), 197-216. https://doi.org/10.1017/ $\underline{\mathrm{S} 0958344014000287}$

[12] Zaki, A., \& Yunus, M. (2015). Potential of Mobile Learning in Teaching of ESL Academic Writing. English Language Teaching, 8(6), 11-19. https://doi.org/10.5539/elt.v8n6p11

[13] Pachler, N., Bachmair, B., \& Cook, J. (2010). Mobile Learning. Structures, Agency, Practices. Springer: New York.

[14] Huang, Y., Huang, Y., Huang, S., \& Lin, Y. (2012). A Ubiquitous English Vocabulary Learning System: Evidence of Active/Passive Attitudes vs. Usefulness/Ease-of-use. Computers \& Education, 58(1), 273-282. https://doi.org/10.1016/i.compedu.2011.08.008

[15] Tafazoli, D., Parra, M., \& Huertas-Abril, C. (2018). Cross-Cultural Perspectives on Technology-Enhanced Language Learning. Hershey, USA: IGI Global.

[16] Trilling, B., \& Fadel, C. (2009). 21st century skills: Learning for Life in our Times. San Francisco: Jossey-Bass. 
[17] O’Bannon, B., Thomas, K. (2015). Mobile Phones in the Classroom: Preservice Teachers Answer the Call. Computers \& Education, 85, 110-122. https://doi.org/10.1016/j.compedu. $\underline{2015.02 .010}$

[18] Thomas, K., O’Bannon, B., \& Britt, V. Standing in the Schoolhouse Door: Teacher Perceptions of Mobile Phones in the Classroom. Journal of Research on Technology in Education, 46(4), 373-395. https://doi.org/10.1080/15391523.2014.925686

[19] Beland, L., \& Murphy, R. (2015). Technology, Distraction \& Student Performance. Department of Economics Working Paper Series. Retrieved from http://cep.lse.ac.uk/pubs/ download/dp1350.pdf

[20] Chartrand, R. (2016). Advantages and Disadvantages of Using Mobile Devices in a University Language Classroom. Bulletin of the Institute of Foreign Language Education Kurume University, 23, 1-13. Retrieved from https://swsu.ru/sbornik-statey/pdf/gaiken23_1-13.pdf

[21] Gikas, J., \& Grant, M. (2013). Mobile Computing Devices in Higher Education: Student Perspectives on Learning with Cellphones, Smartphones \& Social Media. The Internet and Higher Education, 19, 18-26. https://doi.org/10.1016/j.iheduc.2013.06.002

[22] Gehlen-Baum V., Weinberger A. (2012) Notebook or Facebook? How Students Actually Use Mobile Devices in Large Lectures. In: Ravenscroft A., Lindstaedt S., Kloos C.D., Hernández-Leo D. (Eds) 21st Century Learning for 21st Century Skills. EC-TEL 2012. Lecture Notes in Computer Science, vol 7563. Springer, Berlin, Heidelberg. https://doi. org/10.1007/978-3-642-33263-0_9

[23] Gong, Z. (2012). A Comparative Analysis of iPad and Other M-learning Technologies: Exploring Students' View of Adoption, Potentials, and Challenges. Journal of Literacy and Technology, 13(1), 2-29. Retrieved from http://midwestwisconsinreadingcouncil.pbworks. com/w/file/fetch/59830200/iPads\%20and\%20Mobile\%20Learning\%2C\%20Journal\%20of\%20LIteracy\%20and\%20Technology.pdf

[24] Lindaman, D., Nolan, D. (2015). Mobile-Assisted Language Learning: Application Development Projects within Reach for Language Teachers. IALLT Journal of Language Learning Technologies, 45(1), 1-22. Retrieved from http://ialltjournal.org/index.php/ialltjournal/ article/view/64 https://doi.org/10.17161/iallt.v45i1.8547

[25] Viberg, O., \& Grönlund, A. (2013). Cross-cultural Analysis of Users' Attitudes toward the Use of Mobile Devices in Second and Foreign Language Learning in Higher Education: A case from Sweden and China. Computers \& Education, 69, 169-180. https://doi.org/10.10 16/j.compedu.2013.07.014

[26] Grimshaw, J., Cardoso, W., \& Collins, L. (2017). Teacher perspectives on the Integration of mobile-assisted language learning. In CALL in a Climate of Change: Adapting to Turbulent Global Conditions - Short Papers from EUROCALL 2017, pp. 135-139. https://doi. org/10.14705/rpnet.2017.eurocal12017.702

[27] Carrasco, B., \& Johnson, S. (2015). Hybrid Language Teaching in Practice. Perceptions, Reactions, and Results. Heidelberg: Springer.

[28] Mojaye, E. (2015). Mobile Phone Usage among Nigerian University Students and its Impact on teaching and Learning. Global Journal of Arts Humanities and Social Sciences, 3(1), 2938. Retrieved from http://www.eajournals.org/wp-content/uploads/Mobile-Phone-Usageamong-Nigerian-University-Students-and-Its-Impact-On-Teaching-And-Learning.p df https://doi.org/10.18844/ijire.v5i2.1251

[29] Mobinizad, M. (2018). The Use of Mobile Technology in Learning English Language. Theory and Practice in Language Studies, 8(11), 1456-1468. https://doi.org/10.17507/tpls. $\underline{0811.10}$ 
[30] Dashtestani, R. (2016). Moving Bravely towards Mobile Learning: Iranian Students' Use of Mobile Devices for Learning English as a Foreign Language. Computer Assisted Language Learning, 29(4), 815-832. https://doi.org/10.1080/09588221.2015.1069360

[31] Kuznekoff, J., \& Titsworth, S. (2013). The Impact of Mobile Phone Usage on Student Learning. Communication Education, 62, 233-252. https://doi.org/10.1080/03634523.20 13.767917

[32] Tindell, D. R., \& Bohlander, R. W. (2012). The Use and Abuse of Cell Phones and Text Messaging in the Classroom: A Survey of College Students. College Teaching, 60(1), 1-9. https://doi.org/10.1080/87567555.2011.604802

[33] Rosman, P. (2008). M-Learning - A Paradigm of New Forms in Education. Economics and Management, 11(1), 119-125. Retrieved from http://www.ekonomie-management.cz/ download/1331826665_1cdd/13_rosman.pdf

[34] Muhammad, A., Ahamd, F., \& Shah, A. (2015). Resolving Ethical Dillemma in Technology Enhanced Education through Smart Mobile Devices. International Arab Journal of e-Technology, 4(1), 25-31. Retrieved from https://www.iajet.org/iajet_files/vol.4/no.1/4.pdf

[35] Nilsson L. (2015) Technology As a Double Edged Sword: A Promise Yet to be Fulfilled or a Vehicle for Cheating?. In: Bretag T. (Ed.) Handbook of Academic Integrity. Springer, Singapore. https://doi.org/10.1007/978-981-287-079-7_21-2

[36] Ataro, E., Madara, D., \& Sitati, S. (2016). Design and Testing of mobile Phone Detectors. Innovative Systems Design and Engineering, 7(9), 6-14.

[37] McCabe, D., Trevino, L., \& Butterfield, K. (2001). Cheating in Academic Institutions: A Decade of Research. Ethics \& Behavior, 11(3), 219-232. https://doi.org/10.1207/s1532 7019eb1103_2

[38] Saidouni, K., \& Bahloul, A. (2018). The Use of Mobile-Assisted Language Learning in EFL Teaching and Learning Practices and Readiness. Trans Internet Journal for Cultural Studies, 22. Retrieved from http://www.inst.at/trans/22/the-use-of-mobile-assisted-language-learning-in-efl-teaching-and-learning-practices-and-readiness/ https://doi.org/10.35553/1699-000-021-030

[39] Thomas, K., \& O’Bannon, B. (2013). Cell Phones in the Classroom. Journal of Digital Learnin in Teacher Education, 30(1), 11-20. https://doi.org/10.1080/21532974.2013.10784 $\underline{721}$

[40] Bower, M., \& Sturman, D. (2015). What are the Educational Affordances of Wearable Technologies? Computers \& Education, 88, 343-353. https://doi.org/10.1016/j.compedu.20 $\underline{15.07 .013}$

[41] Abidin, Z., Mathrani, A., Parsons, D., \& Suriadi, S. (2015). Opportunities and Challenges of Mobile learning for Promoting Mathematical Literacy. Australasian Conference on Information Systems.

[42] Tsoni, R., \& Lionarakis, A. (2014). Plagiarism in Higher Education: The Academics' Perception. International Conference on Interactive Mobile Communication Technologies and Learning (IMCL), pp. 296-300. Retrieved from https://ieexplore.iee.org/stamp/stamp. jsp?tp=\&arnumber=7011151 https://doi.org/10.1109/imctl.2014.7011151

[43] Curran, K., Middleton, G., \& Doherty, C. (2011). Cheating in Exams with Technology. International Journal of Cyber Ethics in Education (IJCEE), 1(2), 54-62. Retrieved from http://uir.ulster.ac.uk/20622/1/IJCEECheating.pdf https://doi.org/10.4018/ijcee.2011040105

[44] Nyamawe, A., \& Mtonyole, N. (2014). The Use of Mobile Phones in University Exams Cheating: Proposed Solution. International Journal of Engineering Trends and Technology, 17(1), 14-17. Retrieved from http://www.ijettjournal.org/volume-17/number-1/IJETT-V1 7P203.pdf https://doi.org/10.14445/22315381/ijett-v17p203 
[45] Yusri, K., Goodwin, R., \& Mooney, C. (2015). Teachers and Mobile Learning Perception: towards a Conceptual Model of Mobile Learning for Training. Procedia - Social and Behavioral Sciences, 176, 425-430. https://doi.org/10.1016/j.sbspro.2015.01.492

[46] Kim, D., Rueckert, D., Kim, D., \& Seo, D. (2013). Students' Perceptions and Experiences of Mobile Learning. Language Learning \& Technology, 17(3), 52-73. Retrieved from https://scholarspace.manoa.hawaii.edu/bitstream/10125/44339/1/17_03_kimetal.pdf

[47] Ismail, I., Bokhare, S., Azizan, S., \& Azman, N. (2013). Teaching via Mobile Phone: A Case Study on Malaysian Teachers' Technology Acceptance and Readiness. The Journal of Educators Online, 10(1), 1-38. Retrieved from https://files.eric.ed.gov/fulltext/EJ1004895. pdf https://doi.org/10.9743/jeo.2013.1.3

[48] Issham, I, Siti, F. B., Siti, N. A., \& Nizuwan, A. (2013). Teaching via Mobile Phone: A Case Study on Malaysian Teachers' Technology Acceptance and Readiness. School of Distance Learning, Universiti Sains Malaysia.

[49] Serin, O. (2012). Mobile Learning Perceptions of the Prospective Teachers (Turkish Republic of Northern Cyprus Sampling). The Turkish Online Journal of Educational Technology, 11(3), 222-233. Retrieved from http://www.tojet.net/articles/v11i3/11321.pdf

[50] Şad, N., \& Göktaş, Ö. (2014). Preservice Teachers' Perceptions about Using Mobile Phones and Laptops in Education as Mobile Learning Tools. British Journal of Educational Technology, 45(4), 606-618. https://doi.org/10.1111/bjet.12064

[51] Ismail, I., Azizan, S., \& Azman, N. (2013). Mobile Phone as Pedagogical Tools: Are Teaches Ready? International Education Studies, 6(3), 36-47. https://doi.org/10.5539/ies. v6n3p36

[52] Christensen, R., \& Knezek, G. (2017). Readiness for Integrating Mobile Learning in the Classroom: Challenges, Preferences and Possibilities. Computers in Human Behavior, 76, 112-121. https://doi.org/10.1016/j.chb.2017.07.014

[53] West, D. (2013). Mobile Learning: Transforming Education, Engaging Students, and Improving Outcomes. Center for Technology Innovation at Brookings. Retrieved from http://www.scienceisaverb.com/Mobile\%20Learning\%20Transforming\%20Education,\%20Engaging.pdf

\section{$7 \quad$ Author}

Rastislav Metruk works at the Department of English Language and Literature, Faculty of Humanities, University of Žilina, currently holding the position of the head of the department.

Dr. Metruk graduated from the Constantine the Philosopher University in Nitra, Faculty of Education in 2012 with a degree in Teacher Training of English Language and Literature.

In 2016, he completed a Ph.D. degree in English Language at the Department of English and American Studies, Faculty of Arts, University of Ostrava.

He focuses his research on English phonetics and phonology, developing language skills (predominantly the speaking and listening skills) of EFL learners, teaching and assessing English as a foreign language, and the use of ICT in language teaching and learning.

Article submitted 2019-07-18. Resubmitted 2019-09-13. Final acceptance 2019-09-23. Final version published as submitted by the authors. 